\title{
SINKRONISASI MAQOSID AS SYARIAH DAN KONSEP KESETARAAN GENDER DALAM KONSEP IDDAH
}

\author{
Dwi Hidayatul Firdaus \\ Fakultas Syariah UIN Maulana Malik Ibrahim Malang \\ E-mail: elfirdausy2015@gmail.com
}

\begin{abstract}
Gender is construction and social order about various differences between two sexes which related to social relationships between men and women, or a characteristic which has been specified socially and culture. To understand concept of justice and gender equaity it need correct understanding. And for every Muslim ought to understand this gender concept which is related to Islamic law, should be able to synchronize gender concept with the purpose and intention of Islamic law (alMaqasid al-Syar'iyyah) in the form of the benefit to human being, it have to comprehend widely especially in the problem of iddah. The meaning of islamic law basically will realize kindliness of real life to human being, either through individually or socially. Beside aims to form good person, Islamic law also aims to uphold mashlahah and social justice.
\end{abstract}

Gender adalah konstruksi dan tatanan sosial mengenai berbagai perbedaan antara jenis kelamin yang mengacu kepada relasi-relasi sosial antara perempuan dan laki-laki, atau suatu sifat yang telah ditetapkan secara sosial maupun budaya. Memang untuk memahami konsep keadilan dan kesetaraan gender diperlukan pemahaman yang benar. Dan bagi setiap muslim seharusnya memahami konsep gender ini yang bersinggungan dengan hukum Islam, harus bisa mensinkronkan gender tersebut dengan maksud dan tujuan dari hukum Islam (maqasid as-Syar'iyyah) yang berupa kemashlahatan bagi manusia ini harus dipahami secara luas terkhusus masalah iddah. Dalam arti hukum Islam pada dasarnya hendak mewujudkan kebaikan hidup yang hakiki bagi manusia, baik secara individual maupun social. Di samping bertujuan untuk membentuk pribadi yang baik, hukum Islam juga bertujuan untuk menegakkan kemashlahatan dan keadilan social.

Keywords: konsep, kesetaraan gender, maqosid as-syariah, iddah

\section{Pendahuluan}

Diskusi dan polemik tentang keadilan dan kesetaraan (gender issues) dalam Hukum Islam tidak bisa kita lepaskan dari tuntunan Al Qur`an dan Hadist sebagai sumber pokok dari Hukum Islam. Hal ini perlu dikaji secara komprehensif agar tidak terjadi misinterpretasi keadilan dan kesetaraan antara kedudukan laki-laki dan perempuan dalam kenyataan kehidupan sehari-hari menurut Hukum Islam.

Untuk memahami konsep keadilan dan kesetaraan gender diperlukan pemahaman yang benar dalam hukum Islam bagi setiap muslim. Karena aktivitas hidup sehari-hari orang muslim tidak bisa terlepas dari permasalahan hukum Islam, baik ketika ia beribadah kepada Allah atau ketika dia melakukan hubungan sosial antar manusia (muamalah) 
termasuk relasi kesetaraan gender antara laki-laki dan perempuan di tengah-tengah kehidupan masyarakat.

Maksud dan tujuan dari hukum Islam (maqasid as-Syar'iyyah) yang berupa kemashlahatan bagi manusia ini harus dipahami secara luas. Dalam arti hukum Islam pada dasarnya hendak mewujudkan kebaikan hidup yang hakiki bagi manusia, baik secara individual maupun sosial.

Di samping bertujuan untuk membentuk pribadi yang baik, hukum Islam juga bertujuan untuk menegakkan kemashlahatan dan keadilan sosial. Karena apabila hal tersebut dapat direalisasikan terhadap permasalahan-permasalahan kehidupan yang kompleks, baik dalam kehidupan berkeluarga, bermasyarakat, politik, perdagangan, birokrasi, maupun wilayah yang lain, niscaya keadilan social dan kemashlahatan umat akan terwujud.

\section{Perspektif Gender}

Gender adalah konstruksi dan tatanan sosial mengenai berbagai perbedaan antara jenis kelamin yang mengacu kepada relasi-relasi sosial antara perempuan dan lakilaki, atau suatu sifat yang telah ditetapkan secara sosial maupun budaya (Elizabeth Eviota 1992). Dari istilah tersebut kemudian munculah paham mengenai pembagian peran antara laki-laki dan perempuan secara sosial dan budaya. Peran secara gender, yaitu peran yang didasarkan pada kodrat. Dan peran secara budaya sangatlah terbuka untuk dipertukarkan antara laki-laki dan perempuan, sementara peran kodrati seperti mengalami haid, hamil, melahirkan, dan menyusui pada perempuan adalah peran yang tidak dapat dipertukarkan karena sudah demikian sejak diciptakannya. Istilah gender mengacu pada makna sosial, budaya, dan biologis. Peran gender bisa berubah karena dipengaruhi oleh ideologi, ekonomi, adat, agama, dan sosial budaya, etnik, waktu, tempat, dan kemajuan iptek. Perubahan sosial yang selama ini bersifat androsentris, dapat dilihat sebagai ketimpangan struktural dalam perspektif gender (Susanti, 2000). Berdasar pada pemahaman itulah muncul berbagai aksi perempuan di berbagai kegiatan yang tidak lagi dikuasai oleh laki-laki.

Ada dua kelompok besar dalam diskursus feminisme melalui konsep kesetaraan gender, yang saling bertolak belakang. Pertama adalah sekelompok feminis yang menyatakan konsep gender adalah konstruksi sosial, sehingga perbedaan jenis kelamin tidak perlu mengakibatkan perbedaan peran dan perilaku gener dalam tatanan sosial. Sedangkan kelompok feminis lain yang menganggap perbedaan jenis kelamin akan selalu berdampak terhadap konstruksi konsep gender dalam kehidupan sosial, sehingga akan selalu ada jenisjenis pekerjaan berstereotip gender.

Konsep kesetaraan gender memang merupakan suatu konsep yang sangat rumit dan kontroversial, yang sampai saat ini belum ada konsensus mengenai apa yang disebut kesetaraan antara pria dan wanita, ada yang mangatakan bahwa kesetaraan ini adalah persamaan antara hak dan kewajiban, tetapi masih belum tentu jelas juga, dan ada pula yang mengartikanya dengan konsep mitra kesejajaran antara pria da wanita dan sering juga diartikan bahwa wanita mempunyai hak yang sama dengan pria dalam aktualisasi diri, namun harus sesuai dengan kodratnya masing- masing.

Kesetaraan bukan hanya dengan memberikan perlakuan sama kepada setiap individu yang mempunyai aspirasi dan kebutuhan berbeda, melainkan dengan memberikan perhatian sama kepada setiap individu agar kebutuhannya yang spesifik, dapat terpenuhi, konsep ini dapat disebut "kesetaraan konstektual" artinya: kesetaraan adalah bukan kesamaan (sameness) 
yang sering menuntut persamaan matematis, melainkan lebih kepada kesetaraan yang adil sesuai dengan konteks masing-masing individu.

\section{Bentuk-Bentuk Ketidakadilan Gender}

Berbagaimacam bentuk ketidakadilan gender bayak terjadi dalam berbagai bentuk dan bidang. Menurut Mansour Faqih, ada lima bentuk yang mengakibatkan ketidakadilan gender yang ditimbulkan oleh perbedaan jenis kelamin antara lak-laki dan perempuan yaitu:

a. Subordinasi atau penomorduaan dalam kehidupan politik. Bentuk ketidakadilan ini antara lain berupa penempatan perempuan hanya pada posisi yang kurang penting, posisi yang tidak punya wewenang untuk mempengaruhi proses pembentukan keputusan bahkan keputusan-keputusan yang mempengaruhi masa depannya seperti kebijakan kependudukan dan reproduksi, hak kerja dan lain-lain.

b. Marginalisasi atau pemiskinan perempuan dalam kehidupan ekonomi. Ada beberapa perbedaan jenis dan bentuk, tempat dan waktu serta mekanisme proses pemiskinan perempuan karena adanya perbedaan gender. Adakalanya berasal dari kebijakan pemerintah, tafsir agama, keyakinan tradisi, kebiasaan, bahkan juga asumsi ilmu pengetahuan, tidak hanya ditempat kerja, proses ini juga biasa terjadi dalam rumah tangga.

c. Stereotype atau pelabelan negative dalam kehidupan budaya. Misalnya penandaan pelabelan negative yang berawal dari asumsi bahwa tugas utama perempuan adalah melayani suami. Dari cara pandang seperti inilah mengakibatkan dinomorduakannya pendidikan perempuan. Ada satu ungkapan "buat apa wanita sekolah tinggi-tinggi, nanti juga akan kembali kepekerjaan rumah yaitu mencuci dan memasak" dan lain-lain.

d. Kekerasan (violence) terhadap jenis kelamin tertentu, umumnya perempuan, yang disebabkan perbedaan gender. Kekerasan mulai dari kekerasan fisik (pemerkosaan, maupun pembunuhan) sampai pada kekerasaan yang lebih halus (pelecehan seksual dan penciptaan ketergantungan).

e. Karena peran perempuan adalah mengelola rumah tangga, maka perempuan banyak menanggung beban domestic yang lebih banyak dan lama (double burden). Perempuan bertugas menjaga dan memelihara kerapian dan pemeliharaan dalam rumah tangga. Sosialisasi peran gender tersebut menyebabkan rasa bersalah bagi perempuan jika tidak melaksanakan. Sedangkan bagi kaum laki-laki, tidak merasa bukan saja tanggung jawabnya, bahkan banyak tradisi yang melarangnya untuk berpartisipasi. Wajar jika ada yang berpendapat bahwa relasi antara laki-laki dan perempuan tersebut sebagai hal yang "dianggap" adil dan tidak bertentangan dengan Islam. Padahal sebenarnya hal tersebut hanyalah konstruksi sosial seiring dengan perjalanan sejarah kehidupan manusia.

\section{Faktor-Faktor yang Menyebabkan Ketidaksetaraan Gender}

Adapun faktor-faktor yang menyebabkan ketidaksetaraan gender, diantaranya:

a. Melalui Sosialisasi, Dengan melalui sosialisasi yang sudah membudaya dapat membedakan antara laki-laki dan perempuan. Misalnya, perempuan secara biologis berbeda degan laki-laki, perempuan cenderung pasif, kurang agresif, lemah lembut dan emosional, sementara laki-laki cenderung aktif, agresif, dan 
kuat, sehigga orang tua memperlakukan anak laki-laki dan perempuan sangat berbeda. Perempuan lebih mempunyai larangan lebih banyak daripada laki-laki. Cara pandang dunia tentang hubungan laki-laki dan perempuan dengan proses yang panjang juga mempengaruhi bagaimana seharusnya laki-laki dan perempuan memandang dan menilai dirinya. Proses sosialisasi ini berlangsung sepanjang hidup dan pada tahap inilah terjadi koreksi dan penindasan.

b. Melalui Pembedaan dan Penindasan. Menurut Freud, mengatakan bahwa gender dan seksualitas terbentuk melalui proses simbolik dan psikis yang berlangsung dialam bawah sadar, lewat simbol-simbol linguistik dapat diketahui bahwa laki-laki itu kuat sementara perempuan lemah. Lewat simbol-simbol perempuan memahami bahwa dirinya perempuan bukan laki-laki, sehingga harus menyesuaikan diri dengan norma-norma gender yang terdapat dalam simbolsimbol itu. Agar dapat diterima dalam dunia simbolik manusia harus merepresi kecenderungan-kecenderungan pemberontakan didalam dirinya. Bila tidak maka akan dicemooh. Misalnya, adalah anggapan tidak wajar perempuan menampakkan kecenderungan maskulin sebaliknya tidak pantas laki-laki mencuci piring dan memasak di dapur. Jadi ketidaksetaraan gender terbentuk bukan atas dasar kondisi biologis melainkan melalui proses pembedaan dan represi.

c. Melalui Aparat Ideologis (Ideologikal Apparatus). Diantara aparat- aparat ideologis ini diantaranya adalah adat dan tradisi, keluarga, pendidikan, Negara (hukum dan perundang-undangan), media massa, kapitalisme, sains dan tafsir agama yang menempatkan subjek pada posisi-posisi tertentu, sebagai perempuan, kelas menengah dan berbagai dalih yang ada padanya.

\section{Hakekat Keadilan dan Kesetaraan dalam Islam}

Hakekat keadilan dan kesetaraan gender memang tidak bisa dilepaskan dari konteks yang selama ini dipahami oleh masyarakat tentang peranan dan kedudukan laki- laki dan perempuan di dalam realitas sosial mereka. Masyarakat belum memahami bahwa gender adalah suatu konstruksi/bangunan budaya tentang peran, fungsi dan tanggung jawab sosial antara laki-laki dan perempuan. Disamping itu, penafsiran ajaran agama yang kurang menyeluruh atau cenderung dipahami menurut teks/tulisan kurang memahami realitas/kenyataan, cenderung dipahami secara sepotong-sepotong kurang menyeluruh.

Kesetaraan gender mempunyai arti kesamaan kondisi bagi laki-laki dan perempuan untuk memperoleh kesempatan serta hak-hak yang sama sebagai manusia, agar mampu berperan dan berpartisipasi dalam berbagai kegiatan seperti : politik, hukum, ekonomi, sosial budaya, pendidikan dan lain sebagainya.. Kesetaraan gender juga meliputi penghapusan diskriminasi dan ketidakadilan struktural, baik terhadap laki-laki maupun perempuan. Dengan keadilan gender berarti tidak ada pembakuan peran, beban ganda, dan kekerasan terhadap perempuan maupun laki-laki. Tidak adanya diskriminasi antara perempuan dan lakilaki menjadi tanda terwujudnya kesetaran dan keadilan gender, dengan demikian mereka memiliki akses, kesempatan berpartisipasi dan kontrol atas pembangunan serta memperoleh manfaat yang setara dan adil dari pembangunan.

Prof. Dr. Nasaruddin Umar, mengemukakan ada beberapa ukuran yang dapat digunakan sebagai pedoman dalam melihat prinsip-prinsip kesetaraan gender dalam AlQur'an. Ukuran-ukuran tersebut antara lain sebagai berikut:

1. Laki-laki dan Perempuan Sama-sama sebagai Hamba 
Salah satu tujuan penciptaan manusia adalah untuk menyembah kepada Tuhan (QS. Az-Dzariyat/51:56). Dalam kapasitas manusia sebagai hamba, tidak ada perbedaan antara laki-laki dan perempuan. Keduanya mempunyai potensi dan peluang yang sama untuk menjadi hamba ideal, yaitu dalam Al-Qur'an biasa diistilahkan sebagai orangorang yang bertaqwa, dan untuk mencapai derajat bertaqwa ini tidak dikenal adanya perbedaan jenis kelamin, suku bangsa atau kelompok etnis tertentu. Dalam kapasitas sebagai hamba, laki-laki dan perempuan masing-masing akan mendapatkan penghargaan dari Tuhan sesuai dengan kadar pengabdiannya (Q.S. al-Nahl/16:97).

2. Laki-laki dan Perempuan sebagai Khalifah di Bumi

Maksud dan tujuan penciptaan manusia di muka bumi, selain untuk menjadi hamba yang tunduk dan patuh serta mengabdi kepada Allah swt, juga untuk menjadi khalifah di bumi (QS. Al-An'am/6:165). Kata Khalifah tidak menunjuk kepada salah satu jenis kelamin atau kelompok etnis tertentu. Laki-laki dan perempuan mempunyai fungsi yang sama sebagai khalifah, yang akan mempertanggungjawabkan tugas-tugas kekhalifahannya di bumi, sebagaimana halnya mereka harus bertanggung jawab sebagai hamba Tuhan.

3. Laki-laki dan Perempuan Menerima Perjanjian Primordial

Laki-laki dan perempuan sama-sama mengemban amanah dan menerima perjanjian primordial dengan Tuhan. Seperti diketahui, menjelang seorang anak manusia keluar dari rahim ibunya, ia terlebih dahulu harus menerima perjanjian dengan Tuhannya (QS. Al-A'raf/7:172). Tidak ada seorangpun anak manusia lahir di muka bumi yang tidak berikrar akan keberadaan Tuhan, dan ikrar mereka disaksikan oleh para malaikat. Tidak ada seorangpun yang mengatakan "tidak". Dalam Islam, tanggung jawab individual dan kemandirian berlangsung sejak dini, yaitu sejak dalam kandungan. Sejak awal sejarah manusia dalam Islam tidak dikenal adanya diskriminasi jenis kelamin. Laki-laki dan perempuan sama-sama menyatakan ikrar ketuhanan yang sama. Rasa percaya diri seorang perempuan dalam Islam seharusnya terbentuk sejak lahir, karena sejak awal tidak pernah diberikan beban khusus berupa "dosa warisan" seperti yang dikesankan di dalam tradisi Yahudi-Kristen, yang memberikan citra negatif begitu seseorang lahir sebagai 
perempuan. Dalam tradisi ini, perempuan selalu dihubungkan dengan drama kosmis, di mana Hawa dianggap terlibat di dalam kasus keluarnya Adam dari surga. Al-Qur'an yang mempunyai pandangan positif terhadap manusia, Al-Qur'an menegaskan bahwa Allah memuliakan seluruh anak cucu Adam (Q.S. Al-Isra/17:70). Dalam Al-Qur'an, tidak pernah ditemukan satupun ayat yang menunjukan keutamaan seseorang karena faktor jenis kelamin atau karena keturunan suku bangsa tertentu.

4. Adam dan Hawa, Terlibat secara Aktif dalam Drama Kosmis

Semua ayat yang menceritakan tentang drama kosmis, yakni cerita tentang keadaan Adam dan pasangannya di surga sampai keluar ke bumi, selalu menekankan kedua belah pihak secara aktif dengan menggunakan kata ganti untuk dua orang yakni kata ganti untuk Adam dan Hawa, seperti dapat dilihat dalam beberapa kasus berikut ini: Keduanya diciptakan di surga dan memanfaatkan fasilitas surga (Q.S. Al-Baqarah/2:35); Keduanya mendapat kualitas godaan yang sama dari syaitan (Q.S. Al-A'raf/7:20); Samasama memakan buah khuldi dan keduanya menerima akibat jatuh ke bumi (Q.S. alA'raf/7:22); Sama-sama memohon ampun dan sama-sama diampuni Tuhan (Q.S. AlA'raf/7:23); Sama-sama memohon ampun dan sama-sama diampuni Tuhan (Q.S. AlA'raf/7:23); Setelah di bumi, keduanya mengembangkan keturunan dan saling melengkapi dan saling membutuhkan (Q.S. Al-Baqarah/2:187). Adam dan Hawa disebutkan secara bersama-sama sebagai pelaku dan bertanggung jawab terhadap drama kosmis tersebut. Jadi, tidak dapat dibenarkan jika ada anggapan yang menyatakan 
perempuan sebagai mahluk penggoda yang menjadi penyebab jatuhnya anak manusia ke bumi penderitaan

5. Laki-laki dan Perempuan Sama-sama Berpotensi Meraih Prestasi

Dalam hal peluang untuk meraih prestasi maksimum, tidak ada perbedaan antara laki-laki dan perempuan, sebagaimana ditegaskan secara khusus di dalam tiga ayat AlQur'an (Q.S. Ali Imran/3:195, Q.S. An-Nisa/4:124 dan Q.S. Mu'min/40:40). Ayat-ayat ini mengisyaratkan konsep kesetaraan jender yang ideal dan memberikan ketegasan bahwa prestasi individual, baik dalam bidang spiritual maupun urusan karier profesional, tidak mesti dimonopoli oleh salah satu jenis kelamin saja. Laki-laki dan perempuan memperoleh kesempatan yang sama meraih prestasi optimal. Namun, dalam kenyataan di masyarakat, konsep ideal ini masih membutuhkan tahapan dan sosialisasi, karena masih terdapat sejumlah kendala, terutama kendala budaya yang sulit diselesaikan. Salah satu obsesi Al-Qur'an ialah terwujudnya keadilan di dalam masyarakat.

Dengan melihat paparan yang dikemukakan oleh Prof. Dr. Nasaruddin Umar tersebut di atas, terlihat bahwa di dalam Al-Qur'an, sebetulnya sudah menyebutkan adanya keadilan dan kesetaraan antara laki-laki dan perempuan di dalam Islam. Namun di dalam kenyataan sehari-hari keadilan dan kesetaraan gender seperti yang diamanahkan di dalam Al-Qur'an tersebut bias dikatakan masih jauh dari harapan, termasuk pelaksanaan yang terjadi di dunia yang mayoritas warganya beragama Islam.

\section{Konsep Maqosid as-Syariah}

Allah SWT menurunkan syariat (aturan hukum) tiada lain untuk mengambil kemaslahatan dan menghindari kemudaratan (jalbul mashalih wa dar'u al-mafasid). Aturanaturan hukum yang Allah tentukan hanyalah untuk kemaslahatan manusia. Senada dengan hal tersebut menurut al-Syatibi, seorang mujtahid berkewajiban memberikan pertimbangan hukum terhadap apa yang telah digali dari al-Qur'an atau Sunnah berdasarkan situasi dan kondisi yang mengitari objek hukum. Apabila hukum yang dihasilkan dari ijtihadnya itu tidak cocok diterapkan pada objek hukum karena penerapan hukum itu membawa kemudharatan, maka mujtahid itu harus mencarikan hukum lain yang lebih sesuai, sehingga kemudaratan bisa dihilangkan dan kemaslahatan dapat tercapai. Teori inilah yang dikenal dengan sebutan nazariyyah i'tibar al-ma'al.

Kemaslahatan yang akan diwujudkan itu menurut al-Syatibi terbagi kepada tiga tingkatan, yaitu kebutuhan dharuriyat, kebutuhan hajiyat, dan kebutuhan tahsiniyat. Tingkatan pertama, kebutuhan dharuriyat ialah tingkat kebutuhan yang harus ada atau disebut dengan kebutuhan primer. Bila tingkat kebutuhan ini tidak terpenuhi, akan terancam keselamatan umat manusia baik di dunia maupun di akhirat kelak.

Menurut al-Syatibi ada lima hal yang termasuk dalam kategori ini, yaitu memelihara agama, memelihara jiwa, memelihara akal, memelihara kehormatan dan keturunan, serta memelihara harta. Untuk memelihara lima pokok inilah Syariat Islam diturunkan. Setiap ayat hukum bila diteliti akan ditemukan alasan pembentukannya yang tidak lain adalah untuk memelihara lima pokok diatas.

Tingkatan kedua, kebutuhan hajiyat ialah kebutuhan-kebutuhan sekunder, di mana jika tidak terwujudkan tidak sampai mengancam keselamatannya, namun akan mengalami kesulitan. Syariat Islam menghilangkan segala kesulitan itu. Adanya hukum rukhshah (keringanan) seperti dijelaskan Abd al-Wahhab Khallaf, adalah sebagai contoh dari kepedulian Syariat Islam terhadap kebutuhan ini. Contoh jenis maqasid ini dalam bidang 
ekonomi Islam misalnya mencakup kebolehan melaksanakan akad mudharabhah, muzara'ah, musaqat dan bai' salam, serta berbagai aktivitas ekonomi lainnya yang bertujuan untuk memudahkan kehidupan dan menghilangkan kesulitan.

Tingkatan ketiga, kebutuhan tahsiniyat ialah tingkat kebutuhan yang apabila tidak terpenuhi tidak mengancam eksistensi salah satu dari lima pokok di atas dan tidak pula menimbulkan kesulitan. Tingkat kebutuhan ini berupa kebutuhan pelengkap, hal- hal yang merupakan kepatutan menurut adat istiadat yang sesuai dengan tuntutan moral dan akhlak. Contoh jenis al-maqasid ini adalah antara lain mencakup kesopanan dalam bertutur dan bertindak serta pengembangan kualitas produksi dan hasil pekerjaan. Jenis kemaslahatan ini lebih memberikan perhatian pada masalah estetika dan etika, masuk dalam katagori ini misalnya ajaran tentang kebersihan, berhias, shadaqah dan bantuan kemanusiaan. Kemaslahatan ini juga penting dalam rangka menyempurnakan kemaslahatan primer dan skunder.

\section{Iddah antara Maqosid as-Syariah, Hukum Islam dan Kesetaraan Gender}

Iddah adalah bahasa arab yang berasal dari akar kata adda-ya'uddu-idatan dan jamaknya adalah 'idad yang secara arti kata (etimologi) berarti : "menghitung" atau "hitungan". Kata ini digunakan untuk maksud iddah karena dalam bahasa itu si perempuan yang ber-iddah menunggu berlalunya waktu.

Ulama fiqih menyatakan bahwa 'iddah adalah tenggang waktu tertentu yang harus dihitung oleh seorang perempuan semenjak ia berpisah (bercerai) dengan suaminya, baik perpisahan itu disebabkan karena talak maupun karena suaminya meninggal dunia; dan dalam masa tersebut perempuan tidak dibolehkan kawin dengan laki-laki lain. (Zakaria al-Anshariy: Fath al-Wahhab). Ketentuan 'iddah ini didasarkan pada Alquran surat Baqarah ayat 228 yang artinya:

"wanita-wanita yang ditalak handaklah menahan diri (menunggu) tiga kali quru' tidak boleh mereka Menyembunyikan apa yang diciptakan Allah dalam rahimnya, jika mereka beriman kepada Allah dan hari akhirat. dan suami-suaminya berhak merujukinya dalam masa menanti itu, jika mereka (para suami) menghendaki ishlah. dan Para wanita mempunyai hak yang seimbang dengan kewajibannya menurut cara yang ma'ruf. akan tetapi Para suami, mempunyai satu tingkatan kelebihan daripada isterinya dan Allah Maha Perkasa lagi Maha Bijaksana."

surat Baqarah ayat 234:

"orang-orang yang meninggal dunia di antaramu dengan meninggalkan isteri-isteri (hendaklah Para isteri itu) menangguhkan dirinya (ber'iddah) empat bulan sepuluh hari. kemudian apabila telah habis 'iddahnya, Maka tiada dosa bagimu (para wali) membiarkan mereka berbuat terhadap diri mereka menurut yang patut. Allah mengetahui apa yang kamu perbuat."

surat at-Thalaq ayat 4:

"dan perempuan-perempuan yang tidak haid lagi (monopause) di antara perempuanperempuanmu jika kamu ragu-ragu (tentang masa iddahnya), Maka masa iddah mereka adalah tiga bulan; dan begitu (pula) perempuan-perempuan yang tidak haid. dan perempuan-perempuan yang hamil, waktu iddah mereka itu ialah sampai mereka 
melahirkan kandungannya. dan barang -siapa yang bertakwa kepada Allah, niscaya Allah menjadikan baginya kemudahan dalam urusannya."

Akan tetapi di dalam Alquran tidak dijelaskan sebab atau illat hukum yang mendasari ketentuan iddah. Ulama memberikan argument bahwa iddah disyari'atkan misalnya untuk mengetahui apakah dalam rahim perempuan ada benih atau tidak. Kelompok Syafi'iyyah menyatakan bahwa iddah memiliki tiga fungsi yaitu barâ‘ah al-rahim (membersihkan rahim), ta'abbud (pengabdian diri kepada Tuhan), dan bela sungkawa atas kematian suami (tafajju'). (Al-Syarbiniy: Mughniy al-Muhtaj, Juz III).

Untuk itu, dari segi hikmah adanya iddah adalah pertama, agar tidak ada keraguan tentang kesucian rahim bekas istri, sehingga tidak ada keraguan tentang anak yang dikandung oleh bekas istri apabila ia telah kawin dengan laki-laki lain. Kedua, apabila perceraian itu adalah perceraian yang bekas suami masih berhak rujuk kepada bekas istrinya, maka masa iddah itu adalah masa berfikir bagi bekas suami apakah ia akan kembali menggauli bekas istrinya atau mereka tidak akan bergaul kembali sebagai suami istri. Ketiga, apabila perceraian itu karena salah seorang suami istri meninggal dunia maka masa iddah itu adalah untuk menjaga agar jangan timbul rasa tidak senang dari keluarga suami yang meninggal karena baru saja suaminya wafat, ia telah kawin lagi dengan laki-laki lain.

Di zaman sekarang ini, yang menjadi perdebatan dan fokus pembahasan dari artikel ini adalah perihal keadaan kewajiban dan hak wanita dalam masa iddah jika ditinggal mati suami. Secara aturan iddah wanita yang ditinggal mati adalah empat bulan sepuluh hari. Ini pendapat jumhur ulama', sesuai dengan firman Allah SWT dalam surat al-Baqoroh ayat 234 yang telah disebutkan di atas. Kewajiban yang dimaksud adalah dilarangnya seorang wanita yang ditinggal mati suami untuk keluar rumah.

Untuk saat ini, dengan banyaknya wanita yang berkarir dan mempunyai pekerjaan tetap maka perlu penjelasan hukum yang komprehensif terkait masalah ini. As-Sya'rawi dalam memberikan persyaratan dibolehkannya wanita berkarier diantaranya:

1. Mendapat izin dari walinya, yaitu ayah atau suaminya untuk sebuah pekerjaan yang halal seperti menjadi pendidik para siswi, atau menjadi perawat khusus bagi pasien wanita

2. Tidak bercampur dengan kaum laki-laki atau melakukan khalwat dengan lelaki lain.

3. Tidak berlaku tabaruj dan menampakan perhiasan yang dapat mengundang fitnah.

Larangan keluar rumah bagi wanita karir ini adalah ditujukan untuk berkabung dengan meninggalnya suami, Akan tetapi jika masalah yang dihadapi adalah ketidak mampuan dan tidak adanya sisa warisan yang ditinggalkan oleh suami, maka akan mendesak bagi seorang perempuan untuk mempertahankan kehidupannya dan anak-anaknya. Dan jika ini dikaitkan dengan kaidah ususl fiqih bahwa : menghindari kerusakan besar lebih baik daripada mendahulukan kebaikan yang sedikit. Maka keluar rumah untuk bekerja dan berkarir itu diperbolehkan dengan memperhatikan dari syarat-syarat yang sudah dijelaskan di atas.

Intinya, ketentuan hukum Iddah jika dikaitkan dengan wanita karier bisa berlaku dengan beberapa alasan yang sangat mendesak (hifzdu al nafs dan hifdzu an nasl). Alasan diharuskannya melakukan Iddah tidak hanya alasan hukum akan tetapi semua hal di atas menggambarkan bahwa hukum Islam tidak kaku, jadi sifatnya elastis dan fleksibel sebagai sebuah kepatuhan seorang perempuan akan hukum Allah SWT dan kebaikan bagi dirinya sendiri, sesuai dalam kaidah di sebutkan.

"Hukum itu menyesuaikan dengan perubahan zaman tempat dan keadaan". 
Jika kita analisa dari kaidah fiqh di atas yang merupakan pijakan awal dalam menentukan istinbat hukum (penetapan hukum Islam), sebenarnya tidak ada perbedaan dan pertentangan antara tujuan konsep kesetaraan gender dengan maqosid syariah yang diaplikasikan dalam bentuk ijtihad hukum. Karena sudah seharusnya dalam mencetuskan suatu hukum islam (istinbat hukum) harus mempertimbangkan dari segi tujuan dari hukum itu sendiri (maqasid syariah).

Dalam kasus iddah wanita yang ditinggal mati suami, secara normatif fiqh klasik yang memberikan porsi dilarangnya wanita untuk keluar rumah, dengan berkembangnya zaman dan waktu dan tempat, maka proses kritis (ijtihad) dalam hukum Islam perlu dilakukan pembaharuan dengan tidak bertentangan dengan ketentuan awal dari syariat Islam yang sudah termaktub dalam Al-Qur'an dan Al Hadist. Sedangkan hasil ijtihad (fiqh) itu masih berpeluang untuk dilakukan koreksi sesuai dengan illat dan keadaan yang dialami pada masa sekarang.

Zaman dahulu yang perempuan tabu untuk beraktifitas (muamalah) diranah publik, sekarang sudah berbalik 180 derajat baik laki-laki atau wanita punya kans yang sama dalam beraktifitas dan karir diranah publik. Dan inilah spirit kesetaraan gender yang ingin mewujudkan bahwa laki-laki maupun perempuan itu sama dihadapan Allah SWT dan yang membedakan adalah taqwa. Taqwa di sini mengandung arti melaksanakan perintah dan menjauhi larangan. Gender tidak boleh diartikan mentah-mentah harus semua sama dan mempunyai hak dan kewajiban yang sama, melainkan pengakuan yang sama di hadapan Tuhan harus dibarengi dengan mengikuti aturan-aturan (hukum) yang sudah ditetapkan oleh Allah SWT. Jika aturan itu bersifat qot'i maka harus dilaksanakan. Dan jika ketentuan atau hukum itu ada pada ranah fiqh, maka masih boleh kita otak atik sesuai dengan illat yang mendasari suatu kasus tertentu dengan harus memperhatikan dari maqosid syariahnya.

\section{Penutup}

Dari uraian masalah di atas, ada beberapa hal yang menjadi poin dan perlu disadari bersama, terkait dengan 'iddah. Pertama, maksud dan tujuan 'iddah tidak hanya bertujuan untuk mengetahui tidak hamilnya sorang wanita, akan tetapi ada tujuan lain yang tidak bias gender, yaitu tujuan rekonsiliasi dan berkabung, yang semua pihak saling melaksanakan dengan sadar. Kedua, konsep kesetaraan gender dan maqosid syariah sebagai ruh dalam istinbat hukum Islam saling terkait satu dengan yang lain dalam memberikan spirit penentuan hukum Islam dalam masalah tertentu yang rentan akan bias gender. Seperti masalah wanita karir yang ditinggal mati suami. Ketiga, mengingat fiqh merupakan hasil ijtihad para ulama atas nash dalam menyikapi fenomena masalah yang ada, tentunya sangat terbuka peluang untuk melakukan rekonstruksi pemikiran fiqh dalam rangka membangun dan menginisiasi fiqh yang berkeadilan gender, sebagaimana asas Islam, yakni asas keadilan dan kemaslahatan bagi manusia.

Hukum yang tidak boleh diotak atik dan berubah adalah hukum yang ada pada alQur'an dan al-Sunnah seperti keharusan poligami, hak pewarisan lelaki dan wanita yang dua berbanding satu, dan hak kesaksian dan lain-lain. Jika hukum itu tidak berasaskan dari dalil qot'i semisal khitan perempuan dan diyat wanita, maka di dalam menetapkan suatu hukum Islam boleh berubah dan harus dikaji dan diteliti dan secara holistic dan komprehensif. 


\section{Daftar Pustaka}

Abdul Wahhab Khallaf, Ilmu Ushul Fikih. Terj. Faiz el Muttaqien Jakarta: Pustaka Amani, 2003.

Asafri Jaya Bakri. Konsep Maqasid syariah Menurut al-Syatibi Jakarta: PT. Raja Grafindo Persada, 1996.

Asmuni, Penalaran Induktif Syatibi dan Perumusan al-Maqosid Menuju Ijtihad yangDinamis, dikutip dari www.yusdani.com

Fathi al-Daraini, al-Fiqh al-Islami al-Muqaran ma'a al-Madzahib, (Damsyik: T.P.,)

Khaled Abou El Fadl, 2003, Speaking in God's Name, yang diterjemahkan ke dalam bahasa Indonesia “Atas nama Tuhan”, oleh R. Cecep Lukman Yasin, Serambi Ilmu Semesta, Jakarta

Khaled Abou El Fadl, 2005, The Great Theft : Wrestling Islam from the Extremis, yang diterjemahkan ke dalam bahasa Indonesia "Selamatkan Islam dari Muslim Puritan", oleh Helmi Mustofa, Serambi Ilmu Semesta, Jakarta;

Prof. Dr. Nazarudin Umar "Prinsip-Prinsip Keadilan Gender dalam Al- Qur'an", yang dimuat dalam file:///C:/Users/HP Pavilion/Downloads/download keadilan dan kesetaraan gender/prinsip-prinsip kesetaraan gender.htm, diunduh dari internet tanggal 18 November 2010 